\title{
Molecular Regulation of Differentiation in Early B-Lymphocyte Development
}

\author{
Mikael Sigvardsson ${ }^{1,2}$ \\ 1 Division of Molecular Hematology, Lund Stem Cell Center, Department of Laboratory Medicine, \\ Lund University, 22184 Lund, Sweden; mikael.sigvardsson@med.lu.se; Tel.: +46-708-320-120 \\ 2 Department of Clinical and Experimental Medicine, Linköping University, SE-581 85 Linköping, Sweden
}

Received: 30 May 2018; Accepted: 28 June 2018; Published: 30 June 2018

Abstract: B-lymphocyte differentiation is one of the best understood developmental pathways in the hematopoietic system. Our understanding of the developmental trajectories linking the multipotent hematopoietic stem cell to the mature functional B-lymphocyte is extensive as a result of efforts to identify and prospectively isolate progenitors at defined maturation stages. The identification of defined progenitor compartments has been instrumental for the resolution of the molecular features that defines given developmental stages as well as for our understanding of the mechanisms that drive the progressive maturation process. Over the last years it has become increasingly clear that the regulatory networks that control normal B-cell differentiation are targeted by mutations in human B-lineage malignancies. This generates a most interesting link between development and disease that can be explored to improve diagnosis and treatment protocols in lymphoid malignancies. The aim of this review is to provide an overview of our current understanding of molecular regulation in normal and malignant B-cell development.

Keywords: B-lymphocyte; development; transcription factors; lymphoid leukemia

\section{Introduction}

The generation of B-lymphocytes in the bone marrow (BM) is a highly complex process guiding multipotent hematopoietic stem cells to become immunoglobulin-expressing B-cells. The differentiation process depends on the orchestrated activities of transcription factor (TF) networks and extracellular signals acting in conjunction to drive the expansion and maturation of progenitor populations. The process is complicated by the fact that cells must undergo Immunoglobulin (Ig) gene recombination and both positive and negative selection events to ensure proper functionality (reviewed in [1]). Even though much of our understanding of this developmental pathway is based on mouse models, there exist several similarities between mouse and human B-cell differentiation [2-4]. Furthermore, it is now evident that the same mechanisms that control normal B-lymphoid development in mice and humans are targeted in B-lymphoid malignancies (reviewed in [5]). The aim of this review is to provide an overview of our knowledge about developmental trajectories and regulatory networks in normal early B-lymphocyte development and their potential involvement in malignant transformation.

\section{Resolving Developmental Trajectories in B-Cell Development}

In order to understand the process controlling the generation of highly specified blood cells, it is of critical importance to identify and prospectively isolate cells at defined maturation stages. B-lymphocyte development has been suggested to proceed from the hematopoietic stem cell, through the lymphoid primed multipotent progenitor (LMPP) [6] stage, to generate a lymphoid-restricted common lymphoid progenitor (CLP) [7]. CLPs have the capacity to generate B-lineage-restricted B220 ${ }^{+}$ Fraction A compartment [8], proceeding in differentiation to generate CD19 ${ }^{+}$cells. 
While the progenitor cells within the classical CLP compartment retain lymphoid linage potentials and display a reduced capacity to generate myeloid cells [7], the inclusion of additional surface markers in the staining protocols has revealed a molecular and functional heterogeneity within this population. Surface expression of Integrin $\alpha(2) \beta(7)$ (LPAM1) or CXCR6 identifies a subpopulation of cells with reduced B but preserved NK/T lineage potential [9], and BST2 expression identifies a dendritic cell population [10]. It is further possible to isolate a $\mathrm{B} 220^{+}$population with preserved combined $\mathrm{B}$ and T-lineage potential within the classical CLP compartment [11,12]. Hence, it has become increasingly clear that the CLP compartment is highly heterogeneous and likely harbors a variety of more or less lineage-restricted progenitors.

One of the earliest markers associated with B-cell progenitors is B220, a heavily glycosylated splice form of the CD45 protein (CD45R) (reviewed in [13]). Expression of B220 in combination with other surface markers, such as CD43 (S7), CD24 (HSA), BP1, CD19, KIT (CD117), CD93 (AA4.1) [8,14-16], and CD25 [17,18], can be used to identify specific subpopulations of B-cell progenitors. Combined with functional and molecular analysis this has allowed for the establishment of a developmental hierarchy instrumental for our understanding of B-cell development (Figure 1). However, while a substantial fraction of the $\mathrm{CD} 19^{-}$B-cell progenitors express B220, functional analysis fails to link B220 expression exclusively to B-lineage-committed progenitors. Rather, a fraction of the B220 ${ }^{+}$cells retain T-cell [11,12,15], NK [19], and even myeloid potential [20,21].

These findings could be seen as evidence that early B-cell development does not follow one distinct path but rather proceeds through multiple pathways whereby lineage potentials are lost in a more or less stochastic manner (Figure 1). This model for lymphocyte development is supported by the finding that early thymic progenitors display combined T-macrophage potential but most have a limited ability to generate B-lineage cells [22]. Furthermore, the fetal liver contains cells with combined B-macrophage or T-macrophage potential [23]. Additional complexity in developmental trajectories in the fetal liver comes with the identification of $\mathrm{B} / \mathrm{T}$ and $\mathrm{B} / \mathrm{NK}$ bi-potent progenitors $[9,24]$. Hence, the difficulty of identifying $\mathrm{CD} 19^{-}$B-lineage committed progenitors could be a consequence of non-linear developmental paths not subject to the restrictions predicted from a hematopoietic tree (Figure 1).

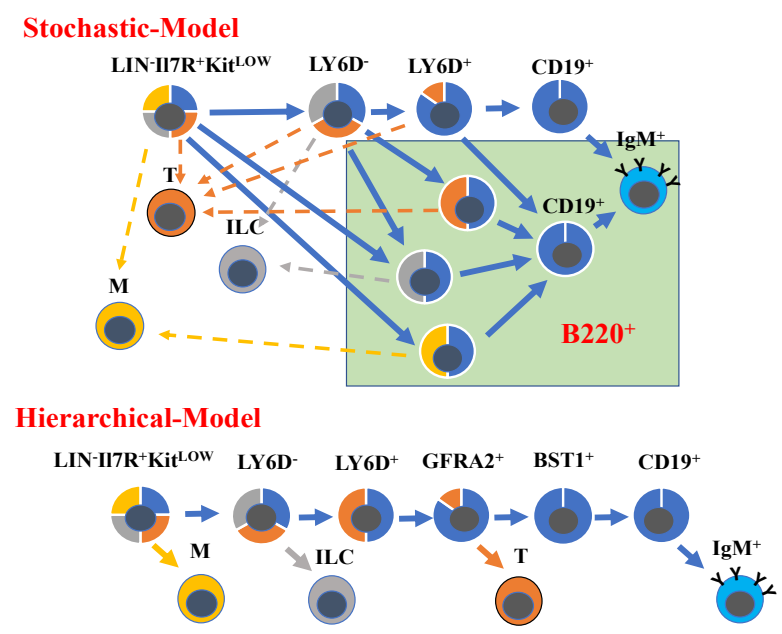

Figure 1. Developmental trajectories in B-cell development. Schematic drawing displaying two models for the developmental trajectories in B-cell development. Yellow indicates myeloid potential (M), gray indicates potential to generate innate lymphoid cells (ILC), orange indicates T lineage potential (T), and blue indicates B-cell potential. The arrows indicate potential developmental trajectories for the defined lineages. The green square indicates $\mathrm{B} 220^{+}$populations.

While conventional surface marker expression did not allow for the prospective isolation of committed CD19- B-cell progenitors, expression of a reporter gene under the control of the Igll1 (Lambda 5) promoter [25] allowed for the identification of B-lymphoid- restricted progenitors within 
the classical CLP compartment [26]. Despite the fact that the Igll1 gene, encoding one of the surrogate light chains [27], is not crucial for the earliest stages of B-cell development [28,29], the gene is transcribed in primitive progenitors serving as a marker for lineage commitment [30,31]. Continued analysis of the cellular heterogeneity within the CLP compartment identified the surface marker Ly6D as being expressed in a subpopulation of cells [32]. Transplantation experiments revealed that the Ly6D" "CLP" population was largely restricted to the production of B-lineage cells; subsequently, these progenitors were denoted B-lymphocyte progenitors BLPs [32]. While the BLP population displayed a minimal T-linage potential in vivo, in vitro differentiation analysis suggested that a fraction of the cells retained the ability to generate T-lineage cells in response to a strong Notch signal [12]. This indicates further heterogeneity within the BLP compartment. This heterogeneity is largely resolved using the expression of the surface markers GNDF family receptor $\alpha 2$ (GFRA2) and bone marrow stroma cell antigen 1 (BST1), to prospectively isolate BLP1, BLP2, and BLP3 cells displaying a progressive degree of commitment to B-cell development [33] (Figure 1). Even though the progenitor populations defined by GFRA2 and BST1 displayed variable levels of B220, their gene expression patterns as well as functional analysis suggest that they represent highly similar or even identical developmental stages. These findings would be in line with observations made using multiparameter molecular analysis of human B-lineage development suggesting a hierarchical model based on progressive and ordered loss of lineage potentials (Figure 1) [34].

While CD19 expression marks stably committed B-lineage progenitors, this population is complex and can be further subdivided into defined developmental stages. The most immature cells express KIT, CD127 (IL7Ra), CD49E, CD11A, CD54, and CD43 [17,18,35,36], while CD25 (IL2R $\alpha$ ) is restricted to cells with a functional pre-BCR [17]. The expression of CD2 resembles that of CD25 because it is restricted to cells with cytoplasmic immunoglobulin heavy $(\mathrm{IgH})$ chains [37]. Despite that surface antigens are most useful in the identification of progenitor stages in early B-cell development, a degree of heterogeneity can be observed even within a defined developmental stage [18]. This argues for the use of multiple markers for the identification of any given progenitor population. In all, the development of protocols for the prospective isolation of defined progenitor compartments provides a detailed map of the developmental trajectories in B-cell development generally compatible with the hematopoietic tree.

\section{Transcription Factor Networks Regulating Early B-Cell Development}

With our increasing understanding of the developmental trajectories in early B-cell development, it has been possible to explore molecular interplay at defined developmental stages. While lineage-specific gene expression is often associated with functional lineage commitment, it has been reported that the expression of lineage-associated genes can be detected already in multipotent progenitors $[38,39]$. These early transcriptional programs are suggested to be associated with defined cell fates [40], indicating the existence of functional lineage priming in non-committed progenitors (Figure 2). Lymphoid lineage priming is mainly observed as activation of genes expressed in both B- and T-cells, including Rag1 and Dntt $[39,41]$. The activation of these genes is dependent on the TFs TCF3 [42-44], IKZF1 (IKAROS) [45], SPI1 (PU.1) [46,47], and MYB [48] acting in a concerted manner to promote the development of lymphoid progenitors. While SPI1 and IKZF1 create a regulatory loop controlling lymphoid versus myeloid cell fate [49], TCF3 initiates the B-lineage-restricted transcriptional program by activation of the FoxO1 gene [50] (Figure 2). FOXO1 acts in a feed-forward loop with the TF EBF1 [51] to activate the transcription of B-lineage genes during B-cell specification [52-54]. The ability of EBF1 to coordinate the activation of transcriptionally inactive genes in epigenetically silenced chromatin $[55,56]$ is likely a consequence of EBF1 associating with chromatin remodeling complexes, thereby directly impacting the structure and the epigenetic landscape $[57,58]$. Despite the LY6D" "CLP" compartment being intact or even increased in the absence of EBF1 $[59,60]$, the GFRA2 ${ }^{+}$compartment is dramatically decreased [33], the transcription of B-lineage-restricted genes is lost [51,52], and the cells are not properly lineage-restricted [60]. This highlights the essential role of EBF1 in B-lineage specification. 


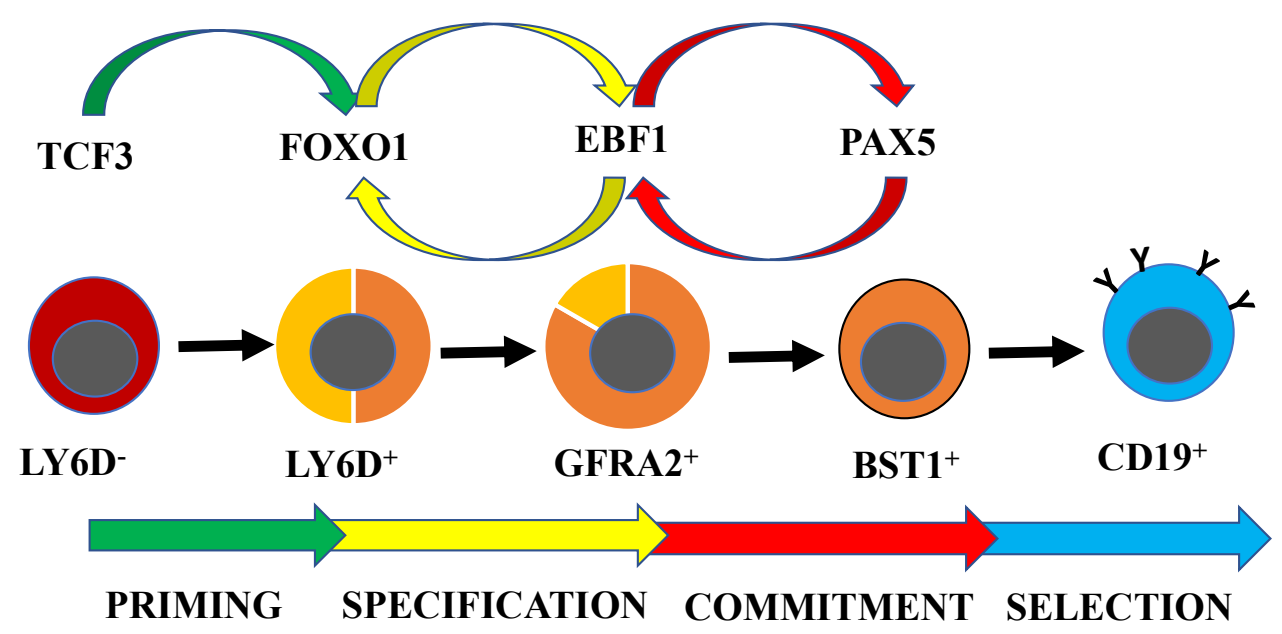

Figure 2. Schematic drawing of the transcription factor networks involved in priming (green arrows), specification (yellow arrows), commitment (red arrows), and selection (blue arrows) in early B-cell development. Red indicates B/T and NK cell potential, orange indicates B-cell potential, and yellow indicates residual T-cell potential. Blue indicates $\operatorname{IgM}^{+}$cells.

Even though EBF1 has the ability to repress genes associated with alternative cell fates $[61,62]$ and the loss of EBF1 in B-lineage cells results in plasticity [63], stable lineage commitment depends on the TF PAX5. Despite a large portion of the B-lineage-restricted transcriptional program being activated in the absence of PAX5 [64,65], the progenitor cells are not stably committed to B-lineage cell fate [65-69]. In vitro differentiation or transplantation of PAX5-deficient pro-B cells, as well as deletion of the Pax5 gene in B-lineage cells, results in the formation of both myeloid and T-lineage cells in vivo and in vitro [65-71]. Lineage restriction is likely achieved through direct repression of target genes such as Colony-stimulating factor receptor 1 (Csf1r or c-fms) gene [72] and Notch1 [73]. Even though this suggests that lineage specification can be separated from commitment [65], the finding that PAX5 is a direct EBF1 target [74] links these two processes in normal development. PAX5 and EBF1 target control elements in the Ebf1 gene [75,76], creating a second regulatory loop and resulting in functional lineage commitment (Figure 2). The importance of the reciprocal regulation and collaboration between EBF1 and PAX5 is highlighted by the finding that normal as well as malignant pro-B cells carrying trans heterozygote mutations in the Ebf1 and Pax5 genes display lineage plasticity [77,78].

In addition to their function in stable lineage commitment, EBF1 and PAX5 are critical regulators of genes encoding proteins forming the pre-B cell receptor (pre-BCR) [54,79-82]. This receptor is formed as a newly generated IGH chain complex with surrogate light chains IGLL1 ( $\lambda 5)$ and VPREB as well as the signal transduction proteins CD79 $\alpha$ and CD79 $\beta$ (reviewed in $[1,83]$ ). Combined signaling through the pre-BCR and the IL7 receptor stimulates a proliferative burst [84] and causes a reduction in RAG protein levels [85]. While the proliferative burst is of great importance for the expansion and overall production of B-lineage cells, progressive development and Ig light chain rearrangement depend on the cells exiting the cell cycle $[86,87]$. This maturation step is suggested to depend on a pre-BCR-mediated activation of a regulatory network involving interferon regulatory factor (IRF4) and PAX5 [88]. PAX5 targets and activates the Ikzf3 gene [89], encoding a TF suggested to collaborate with IKZF1 to repress genes encoding surrogate light chain components [90]. This results in a reduction of pre-BCR levels on the surface of the pro-B cell, reducing the proliferative signal. IRF4 has a somewhat different role in this process since it collaborates with the transcription factor FOXO1, stabilized by the pre-BCR signal [88], to drive differentiation and reactivate Rag gene expression critical for recombination of the Ig light chain genes [91-93]. Furthermore, IRF4 increases the expression of the CXCL12-responsive chemokine receptor CXCR4 [87]. This has been suggested to stimulate migration of the pre-B cells to a micromolecular niche with low levels of Il7 to further reduce the proliferative signal [87]. Hence, B-cell 
development is driven by an intricate interplay between stage-specific regulatory TF networks that orchestrate the differentiation process.

\section{Transcription Factor Networks Link Development to B-Lymphoid Malignancies}

While these TF networks clearly play crucial roles in normal B-cell development, it is becoming increasingly clear that they are closely connected to malignant transformation (reviewed in [5]). This is because genetic alterations in the PAX5, EBF1, or IKZF1 genes are observed in a majority of B-ALL patients [94-96]. Even though there are reports of translocations of TF coding genes resulting in deregulated expression [97,98] or formation of fusion proteins [99-103], the most common genetic alterations result in partial inactivation of one or several TFs [94-96]. Even though inherited point mutations in PAX5 have been reported to result in increased leukemia incidence [104], the reduced functional TF activity more commonly depends on the inactivation of the TF genes via somatic heterozygote mutations and deletions [94-96]. The importance of TF dose for normal blood cell development in mice is well established because heterozygote inactivation of the Myb [48], Spi1 [105], Bcl11a [106], Ikzf1 [107], or Ebf1 [108] gene results in disturbances in B-cell differentiation. Despite the fact that the heterozygote inactivation of the Pax 5 gene in mice does not appear to result in any dramatic developmental block $[109,110]$, it has been suggested to result in alterations of cellular metabolism that may promote transformation [111]. Furthermore, PAX5 deletions are often found in combination with complex karyotypes and other genetic aberrations, including recurrent translocations like $\mathrm{t}(12 ; 21)(\mathrm{p} 13 ; \mathrm{q} 22)$ (ETV6-RUNX1) or $\mathrm{t}(1 ; 19)$ (q23;p13) (TCF3-PBX1) [94,96]. PAX5 mutations are also found in combination with genetic alterations in other TFs such as IKZF1 and EBF1 [94,96], likely augmenting the effect of a reduced PAX5 dose. Interestingly, the phenotypic changes in B-cell development in mice carrying heterozygote inactivation of a TF gene are often exacerbated upon combined targeting of two TFs. Combined heterozygote inactivation of Ebf1/Tcf3 [108], Ebf1/Runx1 [112], or Ebf1/Pax5 [113] results in more dramatic phenotypes than what is observed in the single mutants. This highlights the importance of functional and correctly balanced TF networks in B-cell development.

Even though leukemia is generally considered to be confined to one defined hematopoietic lineage, about $7 \%$ of patients display a more complex disease [114,115]. These malignancies are denoted as acute leukemia of ambiguous lineage (ALAL). ALAL can be manifested either as bi-lineal leukemia, involving several lineages, or bi-phenotypic disease, with expansion of cells displaying combined expression of normally lineage-restricted surface markers [114-116]. It has been reported that the level of PAX5 regulates the formation of bi-phenotypic leukemia [117] and that B-ALL cells carrying mutations in Pax 5 can be converted into other lineages with preserved malignant features [78,118]. Furthermore, in MYC-induced lymphoma, oscillations in EBF1 and PAX5 levels result in lineage plasticity [119]. Additionally, dramatic phenotypic changes with preserved cytogenetic features have occasionally been reported from patients experiencing relapse of disease [120], further challenging the idea that leukemia is restricted to a given lineage of cells. While this has been considered uncommon in clinical practice $[114,115]$, novel treatment protocols may reveal a higher degree of complexity in B-ALL. Recently it was reported that 13 out of 20 patients relapsing after treatment of B-ALL with genetically manipulated T-lymphocytes (chimeric antigen receptor (CAR-T) cells) targeting CD19 developed CD19 negative leukemia even at the clonal level [121,122]. This makes lineage plasticity a central mechanism for resistance development upon targeted treatment of leukemia. Hence, disruptions in transcription factor networks in leukemia may impact not only the transformation process per se but may also underlie the development of resistance to lineage-targeted therapies.

\section{Integration of External Signals and Transcription Factor Networks in Early B-Cell Development}

Even though intrinsic cell events such as regulatory loops created by TF networks are of critical importance for B-cell differentiation, the normal development and expansion of progenitors depend on extracellular signals in the microenvironment. While some of these signals are shared 
with other hematopoietic progenitors, others are restricted to lymphoid progenitor compartments. Among the former are Kit ligand (Steel factor, Stem Cell Factor SCF), acting via the receptor tyrosine kinase cKIT [123]. This receptor is expressed in a variety of hematopoietic progenitor cells including the multipotent hematopoietic stem cells [124], myeloid progenitors [125,126] as well as the CLPs [7]. Subsequently, disruption of this signaling pathway results in defective formation of multiple hematopoietic lineages [127-129]. The expression of cKIT is rather restricted in B-lymphoid progenitors, but a substantial fraction of the pro-B cell compartment retains this surface receptor as well as an ability to respond to the cytokine [130]. CXCL12 is another broadly acting cytokine involved in the homing of cells to specific niches in the BM [131,132]. The protein acts via its surface receptor CXCR4 and both the ligand and the receptor are crucial for normal homing of hematopoietic progenitor cells [131,132], including B-cell progenitors [133]. The expression of CXCL12 is restricted to specific subpopulations of stroma cells in the BM [131], contributing to the ability of this chemokine to act as an organizer of the BM microenvironment.

B-cell development is also influenced by cytokines with more restricted activity. These include FLT3 ligand (FL) acting through the FLT3 receptor expressed in the earliest lineage-restricted progenitor cells. Both the LMPP [6] and the CLPs [134] express FLT3; however, upon progression of B-cell development, the expression is downregulated as a consequence of the Flt3 gene being repressed by PAX5 [135]. Ectopic expression of the FLT3 ligand causes alterations in blood cell development [136] and disruption of this signaling pathway results in reductions in LMPPs and CLPs [137]. However, this occurs without dramatic changes to the peripheral CD19+ B-cell compartments [137]. The phenotype is exacerbated when combined with inactivation of Il7 signaling since this results in a complete block in BM B-cell development [138]. In line with the idea that the II7R is expressed on CLPs with all lymphoid lineage potentials [7], lineage tracing analysis suggests that all B- and T-lymphoid cells as well as a substantial portion of the NK cells in the adult mouse have a history of Il7 expression [139]. The IL7 receptor is expressed on B-cell progenitors and a deficiency in either the receptor [140] or the ligand [141] results in a dramatic impairment in B-cell development already in the B-cell-restricted CD19- compartments in the mouse BM $[60,142]$. The Il7 receptor $\alpha$ (IL7R $\alpha)$ chain is also a component of the receptor for thymic stromal lymphopoietin (TSLP), a cytokine acting via the Il7R $\alpha$ and a specific TSLP-receptor [143]. IL7 and TSLP appear to be functionally redundant since ectopic expression of the latter largely rescues B-cell development in IL7-deficient mice [144].

Many cytokines would appear to be permissive, stimulating proliferation and reducing apoptosis in the B-cell progenitors rather than driving development to a specific lineage in an instructive manner. However, while T-cell development can be largely rescued by overexpression of BCL2 in mice deficient in IL7 signaling, this does not fully rescue B-cell development $[145,146]$. This suggests partially distinct functions for IL-7 signaling in the formation of different lymphoid lineages. One potential explanation for this could be that STAT5 activation, resulting from IL7R signaling [147], induces Ebf1 transcription, potentially driving the progenitor towards B-cell fate [148]. Furthermore, ectopic expression of EBF1 partially rescues B-cell development in mice lacking IL7 [148] or the BTB/POZ domain transcription factor ZBTB17 (MIZ1), crucial for functional IL7 signaling [149]. While this would suggest that IL7 has unique functions in the induction of the genetic program in early B-cell progenitors, the finding that ectopic expression of FL can rescue B-cell development independently of IL7 argues for a more permissive function [150]. Furthermore, the developmental block imposed by conditional deletion of STAT5, a key mediator of Il7 signaling [147], can be partially rescued by ectopic expression of anti-apoptotic proteins [151]. In all, it would appear that the IL7 signaling pathway has both permissive and instructive components, as supported by the finding that deletion of the pro-apoptotic protein BIM rescues survival but not differentiation of B-cell progenitors in Il7-deficient mice [152].

Despite the function of II7 in human B-cell development being somewhat disputed [153], inactivating mutations in the common gamma chain results in severe combined immunodeficiency in humans [154] and activating mutations in the IL7 signaling pathway are commonly detected in human malignancies [155]. Interestingly, heterozygote deletion of Pax5 or Ebf1, in combination with 
transgenic expression of a constitutive active STAT5, causes a synergistic increase in the formation of B-lineage leukemia [156]. Hence, the interplay between TF networks and extracellular signals is critical for normal B-cell development and disturbances may result in impaired immune response or lymphoid malignancies.

\section{Concluding Remarks}

While the detailed understanding of maturation pathways is often considered a subject mainly relevant to developmental biology, our increased understanding of molecular events involved in malignant transformation highlights the relevance of cell differentiation in malignant transformation. Understanding developmental trajectories can be important for diagnosis since, even though leukemia is caused by expansion of progenitor B-cells, the heterogeneous expression of surface IG suggests that leukemia can reside in both the pro- and pre-B cell compartments [114,115]. The use of more advanced FACS staining protocols may resolve an even higher heterogeneity and possibly better classify leukemia in both the CD19-positive and CD19-negative (ALAL) groups. Furthermore, it is becoming increasingly clear that the regulatory networks that drive normal development are targeted in the transformation process. This is knowledge that can be explored to identify novel diagnostic and therapeutic approaches. Additionally, the understanding of the molecular regulation of lineage stability can be used to predict the risk of relapse through lineage conversion in association with targeted therapies. Hence, it can be predicted that basic developmental biology will become of increasing importance for the improvement of modern cancer care in the near future.

Funding: This work was supported by grants from the Swedish Cancer Society, the Swedish Childhood Cancer Foundation, the Swedish Research Council including the Stem Therapy and BioCare programs, Knut and Alice Wallenberg's Foundation, and a donation from Henry Hallberg.

Acknowledgments: I wish to acknowledge my colleagues at Lund and Linköping Universities for stimulating discussions.

Conflicts of Interest: The author declares no conflict of interest.

\section{References}

1. Melchers, F. Checkpoints that control B cell development. J. Clin. Investig. 2015, 125, 2203-2210. [CrossRef] [PubMed]

2. Ghia, P.; ten Boekel, E.; Rolink, A.G.; Melchers, F. B-cell development: A comparison between mouse and man. Immunol. Today 1998, 19, 480-485. [CrossRef]

3. Ghia, P.; ten Boekel, E.; Sanz, E.; de la Hera, A.; Rolink, A.; Melchers, F. Ordering of human bone marrow B lymphocyte precursors by single-cell polymerase chain reaction analyses of the rearrangement status of the immunoglobulin H and L chain gene loci. J. Exp. Med. 1996, 184, 2217-2229. [CrossRef] [PubMed]

4. Ghia, P.; Gratwohl, A.; Signer, E.; Winkler, T.H.; Melchers, F.; Rolink, A.G. Immature B cells from human and mouse bone marrow can change their surface light chain expression. Eur. J. Immunol. 1995, 25, 3108-3114. [CrossRef] [PubMed]

5. Somasundaram, R.; Prasad, M.A.; Ungerback, J.; Sigvardsson, M. Transcription factor networks in B-cell differentiation link development to acute lymphoid leukemia. Blood 2015, 126, 144-152. [CrossRef] [PubMed]

6. Adolfsson, J.; Mansson, R.; Buza-Vidas, N.; Hultquist, A.; Liuba, K.; Jensen, C.T.; Bryder, D.; Yang, L.; Borge, O.J.; Thoren, L.A.; et al. Identification of flt3 $3^{+}$lympho-myeloid stem cells lacking erythro-megakaryocytic potential a revised road map for adult blood lineage commitment. Cell 2005, 121, 295-306. [CrossRef] [PubMed]

7. Kondo, M.; Weissman, I.L.; Akashi, K. Identification of clonogenic common lymphoid progenitors in mouse bone marrow. Cell 1997, 91, 661-672. [CrossRef]

8. Hardy, R.R.; Carmack, C.E.; Shinton, S.A.; Kemp, J.D.; Hayakawa, K. Resolution and characterization of pro-B and pre-pro-B cell stages in normal mouse bone marrow. J. Exp. Med. 1991, 173, 1213-1225. [CrossRef] [PubMed] 
9. Possot, C.; Schmutz, S.; Chea, S.; Boucontet, L.; Louise, A.; Cumano, A.; Golub, R. Notch signaling is necessary for adult, but not fetal, development of ROR $\gamma \mathrm{t}(+)$ innate lymphoid cells. Nat. Immunol. 2011, 12, 949-958. [CrossRef] [PubMed]

10. Medina, K.L.; Tangen, S.N.; Seaburg, L.M.; Thapa, P.; Gwin, K.A.; Shapiro, V.S. Separation of plasmacytoid dendritic cells from B-cell-biased lymphoid progenitor (BLP) and Pre-pro B cells using PDCA-1. PLoS ONE 2013, 8, e78408. [CrossRef] [PubMed]

11. Martin, C.H.; Aifantis, I.; Scimone, M.L.; von Andrian, U.H.; Reizis, B.; von Boehmer, H.; Gounari, F. Efficient thymic immigration of B220+ lymphoid-restricted bone marrow cells with T precursor potential. Nat. Immunol. 2003, 4, 866-873. [CrossRef] [PubMed]

12. Mansson, R.; Zandi, S.; Welinder, E.; Tsapogas, P.; Sakaguchi, N.; Bryder, D.; Sigvardsson, M. Single-cell analysis of the common lymphoid progenitor compartment reveals functional and molecular heterogeneity. Blood 2010, 115, 2601-2609. [CrossRef] [PubMed]

13. Rolink, A.; Melchers, F. B lymphopoiesis in the mouse. Adv. Immunol. 1993, 53, 123-156. [PubMed]

14. Hardy, R.R.; Hayakawa, K. B-lineage differentiation stages resolved by multiparameter flow cytometry. Ann. N. Y. Acad. Sci. 1995, 764, 19-24. [CrossRef] [PubMed]

15. Rumfelt, L.L.; Zhou, Y.; Rowley, B.M.; Shinton, S.A.; Hardy, R.R. Lineage specification and plasticity in CD19- early B cell precursors. J. Exp. Med. 2006, 203, 675-687. [CrossRef] [PubMed]

16. Li, Y.S.; Wasserman, R.; Hayakawa, K.; Hardy, R.R. Identification of the earliest B lineage stage in mouse bone marrow. Immunity 1996, 5, 527-535. [CrossRef]

17. Rolink, A.; Grawunder, U.; Winkler, T.H.; Karasuyama, H.; Melchers, F. IL-2 receptor $\alpha$ chain (CD25, TAC) expression defines a crucial stage in pre-B cell development. Int. Immunol. 1994, 6, 1257-1264. [CrossRef] [PubMed]

18. Jensen, C.T.; Lang, S.; Somasundaram, R.; Soneji, S.; Sigvardsson, M. Identification of Stage-Specific Surface Markers in Early B Cell Development Provides Novel Tools for Identification of Progenitor Populations. J. Immunol. 2016, 197, 1937-1944. [CrossRef] [PubMed]

19. Rolink, A.; ten Boekel, E.; Melchers, F.; Fearon, D.T.; Krop, I.; Andersson, J. A subpopulation of B220 cells in murine bone marrow does not express CD19 and contains natural killer cell progenitors. J. Exp. Med. 1996, 183, 187-194. [CrossRef] [PubMed]

20. Balciunaite, G.; Ceredig, R.; Massa, S.; Rolink, A.G. A B220 ${ }^{+}$CD $117^{+}$CD $19^{ \pm}$hematopoietic progenitor with potent lymphoid and myeloid developmental potential. Eur. J. Immunol. 2005, 35, 2019-2030. [CrossRef] [PubMed]

21. Alberti-Servera, L.; von Muenchow, L.; Tsapogas, P.; Capoferri, G.; Eschbach, K.; Beisel, C.; Ceredig, R.; Ivanek, R.; Rolink, A. Single-cell RNA sequencing reveals developmental heterogeneity among early lymphoid progenitors. EMBO J. 2017, 36, 3619-3633. [CrossRef] [PubMed]

22. Bell, J.J.; Bhandoola, A. The earliest thymic progenitors for T cells possess myeloid lineage potential. Nature 2008, 452, 764-767. [CrossRef] [PubMed]

23. Katsura, Y. Redefinition of lymphoid progenitors. Nat. Rev. Immunol. 2002, 2, 127-132. [CrossRef] [PubMed]

24. Pereira de Sousa, A.; Berthault, C.; Granato, A.; Dias, S.; Ramond, C.; Kee, B.L.; Cumano, A.; Vieira, P. Inhibitors of DNA binding proteins restrict $\mathrm{T}$ cell potential by repressing Notch1 expression in Flt3-negative common lymphoid progenitors. J. Immunol. 2012, 189, 3822-3830. [CrossRef] [PubMed]

25. Martensson, I.L.; Melchers, F.; Winkler, T.H. A transgenic marker for mouse B lymphoid precursors. J. Exp. Med. 1997, 185, 653-661. [CrossRef] [PubMed]

26. Mansson, R.; Zandi, S.; Anderson, K.; Martensson, I.L.; Jacobsen, S.E.; Bryder, D.; Sigvardsson, M. B-lineage commitment prior to surface expression of B220 and CD19 on hematopoietic progenitor cells. Blood 2008, 112, 1048-1055. [CrossRef] [PubMed]

27. Karasuyama, H.; Kudo, A.; Melchers, F. The proteins encoded by the VpreB and 15 pre-B cell-specific genes can associate with each other and with the m heavy chain. J. Exp. Med. 1990, 172, 969-972. [CrossRef] [PubMed]

28. Rolink, A.; Karasuyama, H.; Grawunder, U.; Haasner, D.; Kudo, A.; Melchers, F. B cell development in mice with a defective lambda 5 gene. Eur. J. Immunol. 1993, 23, 1284-1288. [CrossRef] [PubMed]

29. Kitamura, D.; Kudo, A.; Schaal, S.; Muller, W.; Melchers, F.; Rajewsky, K. A critical role of lambda 5 protein in B cell development. Cell 1992, 69, 823-831. [CrossRef] 
30. Kudo, A.; Thalmann, P.; Sakaguchi, N.; Davidson, W.F.; Pierce, J.H.; Kearney, J.F.; Reth, M.; Rolink, A.; Melchers, F. The expression of the mouse VpreB/lambda 5 locus in transformed cell lines and tumors of the B lineage differentiation pathway. Int. Immunol. 1992, 4, 831-840. [CrossRef] [PubMed]

31. Karasuyama, H.; Rolink, A.; Shinkai, Y.; Young, F.; Alt, F.W.; Melchers, F. The expression of Vpre-B/lambda 5 surrogate light chain in early bone marrow precursor B cells of normal and B cell-deficient mutant mice. Cell 1994, 77, 133-143. [CrossRef]

32. Inlay, M.A.; Bhattacharya, D.; Debashis, S.; Serwold, T.; Seita, J.; Karsunky, H.; Plevritis, S.K.; Dill, D.L.; Weissman, I.L. Ly6d marks the earliest stage of B-cell specification and identifies the branchpoint between B-cell and T-cell development. Genes Dev. 2009, 23, 2376-2381. [CrossRef] [PubMed]

33. Jensen, C.T.; Ahsberg, J.; Sommarin, M.N.E.; Strid, T.; Somasundaram, R.; Okuyama, K.; Ungerback, J.; Kupari, J.; Airaksinen, M.S.; Lang, S.; et al. Dissection of progenitor compartments resolves developmental trajectories in B-lymphopoiesis. J. Exp. Med. 2018. [CrossRef] [PubMed]

34. Bendall, S.C.; Davis, K.L.; Amir el, A.D.; Tadmor, M.D.; Simonds, E.F.; Chen, T.J.; Shenfeld, D.K.; Nolan, G.P.; Pe'er, D. Single-cell trajectory detection uncovers progression and regulatory coordination in human B cell development. Cell 2014, 157, 714-725. [CrossRef] [PubMed]

35. Chen, J.; Ma, A.; Young, F.; Alt, F.W. IL-2 receptor $\alpha$ chain expression during early B lymphocyte differentiation. Int. Immunol. 1994, 6, 1265-1268. [CrossRef] [PubMed]

36. Hardy, R.R.; Kincade, P.W.; Dorshkind, K. The protean nature of cells in the B lymphocyte lineage. Immunity 2007, 26, 703-714. [CrossRef] [PubMed]

37. Milne, C.D.; Fleming, H.E.; Paige, C.J. IL-7 does not prevent pro-B/pre-B cell maturation to the immature/sIgM ${ }^{+}$stage. Eur. J. Immunol. 2004, 34, 2647-2655. [CrossRef] [PubMed]

38. Hu, M.; Krause, D.; Greaves, M.; Sharkis, S.; Dexter, M.; Heyworth, C.; Enver, T. Multilineage gene expression precedes commitment in the hemopoietic system. Genes Dev. 1997, 11, 774-785. [CrossRef] [PubMed]

39. Mansson, R.; Hultquist, A.; Luc, S.; Yang, L.; Anderson, K.; Kharazi, S.; Al-Hashmi, S.; Liuba, K.; Thoren, L.; Adolfsson, J.; et al. Molecular evidence for hierarchical transcriptional lineage priming in fetal and adult stem cells and multipotent progenitors. Immunity 2007, 26, 407-419. [CrossRef] [PubMed]

40. Arinobo, Y.; Mizuno, S.; Chong, Y.; Shigematsu, H.; Iino, T.; Iwasaki, H.; Graf, T.; Mayfield, R.; Chan, S.; Kastner, P.; et al. Reciprocal activation of Gata-1 and PU.1 marks initial specification of hematopoietic stem cells into myeloerythroid and myelolymphoid lineages. Cell Stem Cell 2007, 1, 416-427. [CrossRef] [PubMed]

41. Igarashi, H.; Gregory, S.C.; Yokota, T.; Sakaguchi, N.; Kincade, P.W. Transcription from the RAG1 locus marks the earliest lymphocyte progenitors in bone marrow. Immunity 2002, 17, 117-130. [CrossRef]

42. Semerad, C.L.; Mercer, E.M.; Inlay, M.A.; Weissman, I.L.; Murre, C. E2A proteins maintain the hematopoietic stem cell pool and promote the maturation of myelolymphoid and myeloerythroid progenitors. Proc. Natl. Acad. Sci. USA 2009, 106, 1930-1935. [CrossRef] [PubMed]

43. Dias, S.; Mansson, R.; Gurbuxani, S.; Sigvardsson, M.; Kee, B.L. E2A proteins promote development of lymphoid-primed multipotent progenitors. Immunity 2008, 29, 217-227. [CrossRef] [PubMed]

44. Miyai, T.; Takano, J.; Endo, T.A.; Kawakami, E.; Agata, Y.; Motomura, Y.; Kubo, M.; Kashima, Y.; Suzuki, Y.; Kawamoto, H.; et al. Three-step transcriptional priming that drives the commitment of multipotent progenitors toward B cells. Genes Dev. 2018, 32, 112-126. [CrossRef] [PubMed]

45. Yoshida, T.; Ng, S.Y.; Zuniga-Pflucker, J.C.; Georgopoulos, K. Early hematopoietic lineage restrictions directed by Ikaros. Nat. Immunol. 2006, 7, 382-391. [CrossRef] [PubMed]

46. Carotta, S.; Dakic, A.; D'Amico, A.; Pang, S.H.; Greig, K.T.; Nutt, S.L.; Wu, L. The transcription factor PU.1 controls dendritic cell development and Flt3 cytokine receptor expression in a dose-dependent manner. Immunity 2010, 32, 628-641. [CrossRef] [PubMed]

47. DeKoter, R.P.; Lee, H.J.; Singh, H. PU.1 regulates expression of the interleukin-7 receptor in lymphoid progenitors. Immunity 2002, 16, 297-309. [CrossRef]

48. Greig, K.T.; de Graaf, C.A.; Murphy, J.M.; Carpinelli, M.R.; Pang, S.H.; Frampton, J.; Kile, B.T.; Hilton, D.J.; Nutt, S.L. Critical roles for c-Myb in lymphoid priming and early B-cell development. Blood 2010, 115, 2796-2805. [CrossRef] [PubMed]

49. Spooner, C.J.; Cheng, J.X.; Pujadas, E.; Laslo, P.; Singh, H. A recurrent network involving the transcription factors PU.1 and Gfil orchestrates innate and adaptive immune cell fates. Immunity 2009, 31, 576-586. [CrossRef] [PubMed] 
50. Welinder, E.; Mansson, R.; Mercer, E.M.; Bryder, D.; Sigvardsson, M.; Murre, C. The transcription factors E2A and HEB act in concert to induce the expression of FOXO1 in the common lymphoid progenitor. Proc. Natl. Acad. Sci. USA 2011, 108, 17402-17407. [CrossRef] [PubMed]

51. Mansson, R.; Welinder, E.; Ahsberg, J.; Lin, Y.C.; Benner, C.; Glass, C.K.; Lucas, J.S.; Sigvardsson, M.; Murre, C. Positive intergenic feedback circuitry, involving EBF1 and FOXO1, orchestrates B-cell fate. Proc. Natl. Acad. Sci. USA 2012, 109, 21028-21033. [CrossRef] [PubMed]

52. Zandi, S.; Mansson, R.; Tsapogas, P.; Zetterblad, J.; Bryder, D.; Sigvardsson, M. EBF1 is essential for B-lineage priming and establishment of a transcription factor network in common lymphoid progenitors. J. Immunol. 2008, 181, 3364-3372. [CrossRef] [PubMed]

53. Lin, H.; Grosschedl, R. Failure of B-cell differentiation in mice lacking the transcription factor EBF. Nature 1995, 376, 263-267. [CrossRef] [PubMed]

54. Lin, Y.C.; Jhunjhunwala, S.; Benner, C.; Heinz, S.; Welinder, E.; Mansson, R.; Sigvardsson, M.; Hagman, J.; Espinoza, C.A.; Dutkowski, J.; et al. A global network of transcription factors, involving E2A, EBF1 and Foxo1, that orchestrates B cell fate. Nat. Immunol. 2010, 11, 635-643. [CrossRef] [PubMed]

55. Maier, H.; Ostraat, R.; Gao, H.; Fields, S.; Shinton, S.A.; Medina, K.L.; Ikawa, T.; Murre, C.; Singh, H.; Hardy, R.R.; et al. Early B cell factor cooperates with Runx1 and mediates epigenetic changes associated with mb-1 transcription. Nat. Immunol. 2004, 5, 1069-1077. [CrossRef] [PubMed]

56. Li, R.; Cauchy, P.; Ramamoorthy, S.; Boller, S.; Chavez, L.; Grosschedl, R. Dynamic EBF1 occupancy directs sequential epigenetic and transcriptional events in B-cell programming. Genes Dev. 2018, 32, 96-111. [CrossRef] [PubMed]

57. Gao, H.; Lukin, K.; Ramirez, J.; Fields, S.; Lopez, D.; Hagman, J. Opposing effects of SWI/SNF and Mi-2/NuRD chromatin remodeling complexes on epigenetic reprogramming by EBF and Pax5. Proc. Natl. Acad. Sci. USA 2009, 106, 11258-22363. [CrossRef] [PubMed]

58. Yang, C.Y.; Ramamoorthy, S.; Boller, S.; Rosenbaum, M.; Gil, A.R.; Mittler, G.; Imai, Y.; Kuba, K.; Grosschedl, R. Interaction of CCR4-NOT with EBF1 regulates gene-specific transcription and mRNA stability in B lymphopoiesis. Genes Dev. 2016, 30, 2310-2324. [CrossRef] [PubMed]

59. Gyory, I.; Boller, S.; Nechanitzky, R.; Mandel, E.; Pott, S.; Liu, E.; Grosschedl, R. Transcription factor Ebf1 regulates differentiation stage-specific signaling, proliferation, and survival of B cells. Genes Dev. 2012, 25, 668-682. [CrossRef] [PubMed]

60. Tsapogas, P.; Zandi, S.; Ahsberg, J.; Zetterblad, J.; Welinder, E.; Jonsson, J.I.; Mansson, R.; Qian, H.; Sigvardsson, M. IL-7 mediates Ebf-1-dependent lineage restriction in early lymphoid progenitors. Blood 2011, 118, 1283-1290. [CrossRef] [PubMed]

61. Thal, M.A.; Carvalho, T.L.; He, T.; Kim, H.G.; Gao, H.; Hagman, J.; Klug, C.A. Ebf1-mediated down-regulation of Id 2 and Id3 is essential for specification of the B cell lineage. Proc. Natl. Acad. Sci. USA 2009, 106, 552-557. [CrossRef] [PubMed]

62. Pongubala, J.M.; Northrup, D.L.; Lancki, D.W.; Medina, K.L.; Treiber, T.; Bertolino, E.; Thomas, M.; Grosschedl, R.; Allman, D.; Singh, H. Transcription factor EBF restricts alternative lineage options and promotes B cell fate commitment independently of Pax5. Nat. Immunol. 2008, 9, 203-215. [CrossRef] [PubMed]

63. Nechanitzky, R.; Akbas, D.; Scherer, S.; Gyory, I.; Hoyler, T.; Ramamoorthy, S.; Diefenbach, A.; Grosschedl, R. Transcription factor EBF1 is essential for the maintenance of B cell identity and prevention of alternative fates in committed cells. Nat. Immunol. 2013, 14, 867-875. [CrossRef] [PubMed]

64. Nutt, S.L.; Urbanek, P.; Rolink, A.; Busslinger, M. Essential functions of Pax5 (BSAP) in pro-B cell development: Difference between fetal and adult B lymphopoiesis and reduced V-to-DJ recombination at the IgH locus. Genes Dev. 1997, 11, 476-491. [CrossRef] [PubMed]

65. Zandi, S.; Ahsberg, J.; Tsapogas, P.; Stjernberg, J.; Qian, H.; Sigvardsson, M. Single-cell analysis of early B-lymphocyte development suggests independent regulation of lineage specification and commitment in vivo. Proc. Natl. Acad. Sci. USA 2012, 109, 15871-15876. [CrossRef] [PubMed]

66. Mikkola, I.; Heavey, B.; Horcher, M.; Busslinger, M. Reversion of B cell commitment upon loss of Pax5 expression. Science 2002, 297, 110-113. [CrossRef] [PubMed]

67. Nutt, S.L.; Heavey, B.; Rolink, A.G.; Busslinger, M. Commitment to the B-lymphoid lineage depends on the transcription factor Pax5. Nature 1999, 401, 556-562. [CrossRef] [PubMed] 
68. Rolink, A.G.; Nutt, S.L.; Melchers, F.; Busslinger, M. Long-term in vivo reconstitution of T-cell development by Pax5- deficient B-cell progenitors. Nature 1999, 401, 603-606. [CrossRef] [PubMed]

69. Hoflinger, S.; Kesavan, K.; Fuxa, M.; Hutter, C.; Heavey, B.; Radtke, F.; Busslinger, M. Analysis of Notch1 function by in vitro $\mathrm{T}$ cell differentiation of Pax5 mutant lymphoid progenitors. J. Immunol. 2004, 173, 3935-3944. [CrossRef] [PubMed]

70. Rolink, A.G.; Schaniel, C.; Bruno, L.; Melchers, F. In vitro and in vivo plasticity of Pax5-deficient pre-B I cells. Immunol. Lett. 2002, 82, 35-40. [CrossRef]

71. Schaniel, C.; Bruno, L.; Melchers, F.; Rolink, A.G. Multiple hematopoietic cell lineages develop in vivo from transplanted Pax5-deficient pre-B I-cell clones. Blood 2002, 99, 472-478. [CrossRef] [PubMed]

72. Tagoh, H.; Ingram, R.; Wilson, N.; Salvagiotto, G.; Warren, A.J.; Clarke, D.; Busslinger, M.; Bonifer, C. The mechanism of repression of the myeloid-specific c-fms gene by Pax 5 during B lineage restriction. EMBO J. 2006, 25, 1070-1080. [CrossRef] [PubMed]

73. Souabni, A.; Cobaleda, C.; Schebesta, M.; Busslinger, M. Pax5 promotes B lymphopoiesis and blocks T cell development by repressing Notch1. Immunity 2002, 17, 781-793. [CrossRef]

74. Decker, T.; Pasca di Magliano, M.; McManus, S.; Sun, Q.; Bonifer, C.; Tagoh, H.; Busslinger, M. Stepwise activation of enhancer and promoter regions of the B cell commitment gene Pax5 in early lymphopoiesis. Immunity 2009, 30, 508-520. [CrossRef] [PubMed]

75. Roessler, S.; Gyory, I.; Imhof, S.; Spivakov, M.; Williams, R.R.; Busslinger, M.; Fisher, A.G.; Grosschedl, R. Distinct promoters mediate the regulation of Ebf1 gene expression by interleukin-7 and Pax5. Mol. Cell. Biol. 2007, 27, 579-594. [CrossRef] [PubMed]

76. Smith, E.M.; Gisler, R.; Sigvardsson, M. Cloning and Characterization of a Promoter Flanking the Early B Cell Factor (EBF) Gene Indicates Roles for E-Proteins and Autoregulation in the Control of EBF Expression. J. Immunol. 2002, 169, 261-270. [CrossRef] [PubMed]

77. Ungerback, J.; Ahsberg, J.; Strid, T.; Somasundaram, R.; Sigvardsson, M. Combined heterozygous loss of Ebf1 and Pax5 allows for T-lineage conversion of B cell progenitors. J. Exp. Med. 2015, 212, 1109-1123. [CrossRef] [PubMed]

78. Somasundaram, R.; Ahsberg, J.; Okuyama, K.; Ungerback, J.; Lilljebjorn, H.; Fioretos, T.; Strid, T.; Sigvardsson, M. Clonal conversion of B lymphoid leukemia reveals cross-lineage transfer of malignant states. Genes Dev. 2016, 30, 2486-2499. [CrossRef] [PubMed]

79. Treiber, T.; Mandel, E.M.; Pott, S.; Gyory, I.; Firner, S.; Liu, E.T.; Grosschedl, R. Early B Cell Factor 1 Regulates B Cell Gene Networks by Activation, Repression, and Transcription-Independent Poising of Chromatin. Immunity 2010, 32, 714-725. [CrossRef] [PubMed]

80. Revilla, I.D.R.; Bilic, I.; Vilagos, B.; Tagoh, H.; Ebert, A.; Tamir, I.M.; Smeenk, L.; Trupke, J.; Sommer, A.; Jaritz, M.; et al. The B-cell identity factor Pax5 regulates distinct transcriptional programmes in early and late B lymphopoiesis. EMBO J. 2012, 31, 3130-3146. [CrossRef] [PubMed]

81. Nutt, S.L.; Thevenin, C.; Busslinger, M. Essential functions of Pax-5 (BSAP) in pro-B cell development. Immunobiology 1997, 198, 227-235. [CrossRef]

82. Nutt, S.L.; Morrison, A.M.; Dorfler, P.; Rolink, A.; Busslinger, M. Identification of BSAP (Pax-5) target genes in early B-cell development by loss- and gain-of-function experiments. EMBO J. 1998, 17, 2319-2333. [CrossRef] [PubMed]

83. Martensson, I.L.; Rolink, A.; Melchers, F.; Mundt, C.; Licence, S.; Shimizu, T. The pre-B cell receptor and its role in proliferation and Ig heavy chain allelic exclusion. In Seminars in Immunology; Academic Press: Cambridge, MA, USA, 2002; Volume 14, pp. 335-342.

84. Erlandsson, L.; Licence, S.; Gaspal, F.; Lane, P.; Corcoran, A.E.; Martensson, I.L. Both the pre-BCR and the IL-7Ralpha are essential for expansion at the pre-BII cell stage in vivo. Eur. J. Immunol. 2005, 35, 1969-1976. [CrossRef] [PubMed]

85. Grawunder, U.; Leu, T.M.J.; Scatz, D.G.; Werner, A.; Rolink, A.G.; Melchers, F.; Winkler, T.H. Down-regulation of RAG1 and RAG2 gene expression in preB cells after functional immunoglobulin heavy chain rearrangement. Immunity 1995, 3, 601-608. [CrossRef]

86. Mandal, M.; Powers, S.E.; Ochiai, K.; Georgopoulos, K.; Kee, B.L.; Singh, H.; Clark, M.R. Ras orchestrates exit from the cell cycle and light-chain recombination during early B cell development. Nat. Immunol. 2009, 10, 1110-1117. [CrossRef] [PubMed] 
87. Johnson, K.; Hashimshony, T.; Sawai, C.M.; Pongubala, J.M.; Skok, J.A.; Aifantis, I.; Singh, H. Regulation of immunoglobulin light-chain recombination by the transcription factor IRF-4 and the attenuation of interleukin-7 signaling. Immunity 2008, 28, 335-345. [CrossRef] [PubMed]

88. Ochiai, K.; Maienschein-Cline, M.; Mandal, M.; Triggs, J.R.; Bertolino, E.; Sciammas, R.; Dinner, A.R.; Clark, M.R.; Singh, H. A self-reinforcing regulatory network triggered by limiting IL-7 activates pre-BCR signaling and differentiation. Nat. Immunol. 2012, 13, 300-307. [CrossRef] [PubMed]

89. Pridans, C.; Holmes, M.L.; Polli, M.; Wettenhall, J.M.; Dakic, A.; Corcoran, L.M.; Smyth, G.K.; Nutt, S.L. Identification of Pax5 target genes in early B cell differentiation. J. Immunol. 2008, 180, 1719-1728. [CrossRef] [PubMed]

90. Thompson, E.C.; Cobb, B.S.; Sabbattini, P.; Meixlsperger, S.; Parelho, V.; Liberg, D.; Taylor, B.; Dillon, N.; Georgopoulos, K.; Jumaa, H.; et al. Ikaros DNA-binding proteins as integral components of B cell developmental-stage-specific regulatory circuits. Immunity 2007, 26, 335-344. [CrossRef] [PubMed]

91. Lu, R.; Medina, K.; Lancki, D.; Singh, H. IRF-4,8 orchestrate the pre-B-to-B transition in lymphocyte development. Genes Dev. 2003, 17, 1703-1708. [CrossRef] [PubMed]

92. Amin, R.H.; Schlissel, M.S. Foxo1 directly regulates the transcription of recombination-activating genes during B cell development. Nat. Immunol. 2008, 9, 613-622. [CrossRef] [PubMed]

93. Dengler, H.S.; Baracho, G.V.; Omori, S.A.; Bruckner, S.; Arden, K.C.; Castrillon, D.H.; DePinho, R.A.; Rickert, R.C. Distinct functions for the transcription factor Foxo1 at various stages of B cell differentiation. Nat. Immunol. 2008, 9, 1388-1398. [CrossRef] [PubMed]

94. Mullighan, C.G.; Goorha, S.; Radtke, I.; Miller, C.B.; Coustan-Smith, E.; Dalton, J.D.; Girtman, K.; Mathew, S.; Ma, J.; Pounds, S.B.; et al. Genome-wide analysis of genetic alterations in acute lymphoblastic leukaemia. Nature 2007, 446, 758-764. [CrossRef] [PubMed]

95. Mullighan, C.G.; Miller, C.B.; Radtke, I.; Phillips, L.A.; Dalton, J.; Ma, J.; White, D.; Hughes, T.P.; le Beau, M.M.; Pui, C.H.; et al. BCR-ABL1 lymphoblastic leukaemia is characterized by the deletion of Ikaros. Nature 2008, 453, 110-114. [CrossRef] [PubMed]

96. Kuiper, R.P.; Schoenmakers, E.F.; van Reijmersdal, S.V.; Hehir-Kwa, J.Y.; van Kessel, A.G.; van Leeuwen, F.N.; Hoogerbrugge, P.M. High-resolution genomic profiling of childhood ALL reveals novel recurrent genetic lesions affecting pathways involved in lymphocyte differentiation and cell cycle progression. Leukemia 2007, 21, 1258-1266. [CrossRef] [PubMed]

97. Iida, S.; Rao, P.H.; Nallasivam, P.; Hibshoosh, H.; Butler, M.; Louie, D.C.; Dyomin, V.; Ohno, H.; Chaganti, R.S.; Dalla-Favera, R. The $\mathrm{t}(9 ; 14)(\mathrm{p} 13 ; \mathrm{q} 32)$ chromosomal translocation associated with lymphoplasmacytoid lymphoma involves the PAX-5 gene. Blood 1996, 88, 4110-4117. [PubMed]

98. Bouamar, H.; Abbas, S.; Lin, A.P.; Wang, L.; Jiang, D.; Holder, K.N.; Kinney, M.C.; Hunicke-Smith, S.; Aguiar, R.C. A capture-sequencing strategy identifies IRF8, EBF1, and APRIL as novel IGH fusion partners in B-cell lymphoma. Blood 2013, 122, 726-733. [CrossRef] [PubMed]

99. Roberts, K.G.; Morin, R.D.; Zhang, J.; Hirst, M.; Zhao, Y.; Su, X.; Chen, S.C.; Payne-Turner, D.; Churchman, M.L.; Harvey, R.C.; et al. Genetic alterations activating kinase and cytokine receptor signaling in high-risk acute lymphoblastic leukemia. Cancer Cell 2012, 22, 153-166. [CrossRef] [PubMed]

100. Coyaud, E.; Struski, S.; Prade, N.; Familiades, J.; Eichner, R.; Quelen, C.; Bousquet, M.; Mugneret, F.; Talmant, P.; Pages, M.P.; et al. Wide diversity of PAX5 alterations in B-ALL: A Groupe Francophone de Cytogenetique Hematologique study. Blood 2010, 115, 3089-3097. [CrossRef] [PubMed]

101. Kamps, M.P.; Murre, C.; Sun, X.H.; Baltimore, D. A new homeobox gene contributes the DNA binding domain of the $\mathrm{t}(1 ; 19)$ translocation protein in pre-B ALL. Cell 1990, 60, 547-555. [CrossRef]

102. Inaba, T.; Roberts, W.M.; Shapiro, L.H.; Jolly, K.W.; Raimondi, S.C.; Smith, S.D.; Look, A.T. Fusion of the leucine zipper gene HLF to the E2A gene in human acute B-lineage leukemia. Science 1992, 257, 531-534. [CrossRef] [PubMed]

103. Fazio, G.; Palmi, C.; Rolink, A.; Biondi, A.; Cazzaniga, G. PAX5/TEL acts as a transcriptional repressor causing down-modulation of CD19, enhances migration to CXCL12, and confers survival advantage in pre-BI cells. Cancer Res. 2008, 68, 181-189. [CrossRef] [PubMed]

104. Shah, S.; Schrader, K.A.; Waanders, E.; Timms, A.E.; Vijai, J.; Miething, C.; Wechsler, J.; Yang, J.; Hayes, J.; Klein, R.J.; et al. A recurrent germline PAX5 mutation confers susceptibility to pre-B cell acute lymphoblastic leukemia. Nat. Genet. 2013, 45, 1226-1231. [CrossRef] [PubMed] 
105. DeKoter, R.P.; Singh, H. Regulation of B lymphocyte and macrophage development by graded expression of PU.1. Science 2000, 288, 1439-1441. [CrossRef] [PubMed]

106. Yu, Y.; Wang, J.; Khaled, W.; Burke, S.; Li, P.; Chen, X.; Yang, W.; Jenkins, N.A.; Copeland, N.G.; Zhang, S.; et al. Bcl11a is essential for lymphoid development and negatively regulates p53. J. Exp. Med. 2012, 209, 2467-2483. [CrossRef] [PubMed]

107. Ferreiros-Vidal, I.; Carroll, T.; Taylor, B.; Terry, A.; Liang, Z.; Bruno, L.; Dharmalingam, G.; Khadayate, S.; Cobb, B.S.; Smale, S.T.; et al. Genome-wide identification of Ikaros targets elucidates its contribution to mouse B-cell lineage specification and pre-B-cell differentiation. Blood 2013, 121, 1769-1782. [CrossRef] [PubMed]

108. O'Riordan, M.; Grosschedl, R. Coordinate regulation of B cell differentiation by the transcription factors EBF and E2A. Immunity 1999, 11, 21-31. [CrossRef]

109. Urbánek, P.; Wang, Z.-Q.; Fetka, I.; Wagner, E.F.; Busslinger, M. Complete block of early B cell differentiation and altered patterning of the posterior midbrain in mice lacking Pax5/BSAP. Cell 1994, 79, 901-912. [CrossRef]

110. Ahsberg, J.; Ungerback, J.; Strid, T.; Welinder, E.; Stjernberg, J.; Larsson, M.; Qian, H.; Sigvardsson, M. Early B-cell Factor 1 regulates the expansion of B-cell progenitors in a dose dependent manner. J. Biol. Chem. 2013, 288, 33449-33461. [CrossRef] [PubMed]

111. Chan, L.N.; Chen, Z.; Braas, D.; Lee, J.W.; Xiao, G.; Geng, H.; Cosgun, K.N.; Hurtz, C.; Shojaee, S.; Cazzaniga, V.; et al. Metabolic gatekeeper function of B-lymphoid transcription factors. Nature 2017, 542, 479-483. [CrossRef] [PubMed]

112. Lukin, K.; Fields, S.; Lopez, D.; Cherrier, M.; Ternyak, K.; Ramirez, J.; Feeney, A.J.; Hagman, J. Compound haploinsufficiencies of Ebf1 and Runx1 genes impede B cell lineage progression. Proc. Natl. Acad. Sci. USA 2010, 107, 7869-7874. [CrossRef] [PubMed]

113. Prasad, M.A.; Ungerback, J.; Ahsberg, J.; Somasundaram, R.; Strid, T.; Larsson, M.; Mansson, R.; de Paepe, A.; Lilljebjorn, H.; Fioretos, T.; et al. Ebf1 heterozygosity results in increased DNA damage in pro-B cells and their synergistic transformation by Pax5 haploinsufficiency. Blood 2015, 125, 4052-4059. [CrossRef] [PubMed]

114. Jennings, C.D.; Foon, K.A. Recent advances in flow cytometry: Application to the diagnosis of hematologic malignancy. Blood 1997, 90, 2863-2892. [PubMed]

115. Craig, F.E.; Foon, K.A. Flow cytometric immunophenotyping for hematologic neoplasms. Blood 2008, 111, 3941-3967. [CrossRef] [PubMed]

116. Manola, K.N. Cytogenetic abnormalities in acute leukaemia of ambiguous lineage: An overview. Br. J. Haematol. 2013, 163, 24-39. [CrossRef] [PubMed]

117. Simmons, S.; Knoll, M.; Drewell, C.; Wolf, I.; Mollenkopf, H.J.; Bouquet, C.; Melchers, F. Biphenotypic B-lymphoid/myeloid cells expressing low levels of Pax5: Potential targets of BAL development. Blood 2012, 120, 3688-3698. [CrossRef] [PubMed]

118. Jacoby, E.; Nguyen, S.M.; Fountaine, T.J.; Welp, K.; Gryder, B.; Qin, H.; Yang, Y.; Chien, C.D.; Seif, A.E.; Lei, H.; et al. CD19 CAR immune pressure induces B-precursor acute lymphoblastic leukaemia lineage switch exposing inherent leukaemic plasticity. Nat. Commun. 2016, 7, 12320. [CrossRef] [PubMed]

119. Yu, D.; Allman, D.; Goldschmidt, M.H.; Atchison, M.L.; Monroe, J.G.; Thomas-Tikhonenko, A. Oscillation between B-lymphoid and myeloid lineages in Myc-induced hematopoietic tumors following spontaneous silencing/reactivation of the EBF/Pax5 pathway. Blood 2003, 101, 1950-1955. [CrossRef] [PubMed]

120. Dorantes-Acosta, E.; Pelayo, R. Lineage switching in acute leukemias: A consequence of stem cell plasticity? Bone Marrow Res. 2012, 2012, 406796. [CrossRef] [PubMed]

121. Park, J.H.; Geyer, M.B.; Brentjens, R.J. CD19-targeted CAR T-cell therapeutics for hematologic malignancies: Interpreting clinical outcomes to date. Blood 2016, 127, 3312-3320. [CrossRef] [PubMed]

122. Gardner, R.; Wu, D.; Cherian, S.; Fang, M.; Hanafi, L.A.; Finney, O.; Smithers, H.; Jensen, M.C.; Riddell, S.R.; Maloney, D.G.; et al. Acquisition of a CD19-negative myeloid phenotype allows immune escape of MLL-rearranged B-ALL from CD19 CAR-T-cell therapy. Blood 2016, 127, 2406-2410. [CrossRef] [PubMed]

123. Huang, E.; Nocka, K.; Beier, D.R.; Chu, T.Y.; Buck, J.; Lahm, H.W.; Wellner, D.; Leder, P.; Besmer, P. The hematopoietic growth factor KL is encoded by the $\mathrm{Sl}$ locus and is the ligand of the c-kit receptor, the gene product of the $\mathrm{W}$ locus. Cell 1990, 63, 225-233. [CrossRef]

124. Ikuta, K.; Weissman, I.L. Evidence that hematopoietic stem cells express mouse c-kit but do not depend on steel factor for their generation. Proc. Natl. Acad. Sci. USA 1992, 89, 1502-1506. [CrossRef] [PubMed] 
125. Akashi, K.; Traver, D.; Miyamoto, T.; Weissman, I.L. A clonogenic common myeloid progenitor that gives rise to all myeloid lineages. Nature 2000, 404, 193-197. [CrossRef] [PubMed]

126. Pronk, C.; Rossi, D.; Månsson, R.; Attema, J.; Norddahl, G.; Chan, C.; Sigvardsson, M.; Weissman, I.; Bryder, D. Elucidation of the phenotype, functional, and molecular topography of a myeloerythroid progenitor cell hierarchy. Cell Stem Cell 2007, 1, 428-442. [CrossRef] [PubMed]

127. Waskow, C.; Paul, S.; Haller, C.; Gassmann, M.; Rodewald, H.R. Viable c-Kit(W/W) mutants reveal pivotal role for c-kit in the maintenance of lymphopoiesis. Immunity 2002, 17, 277-288. [CrossRef]

128. Miller, C.L.; Rebel, V.I.; Lemieux, M.E.; Helgason, C.D.; Lansdorp, P.M.; Eaves, C.J. Studies of W mutant mice provide evidence for alternate mechanisms capable of activating hematopoietic stem cells. Exp. Hematol. 1996, 24, 185-194. [PubMed]

129. Sharma, Y.; Astle, C.M.; Harrison, D.E. Heterozygous kit mutants with little or no apparent anemia exhibit large defects in overall hematopoietic stem cell function. Exp. Hematol. 2007, 35, 214-220. [CrossRef] [PubMed]

130. Rolink, A.; Streb, M.; Nishikawa, S.; Melchers, F. The c-kit-encoded tyrosine kinase regulates the proliferation of early pre-B cells. Eur. J. Immunol. 1991, 21, 2609-2612. [CrossRef] [PubMed]

131. Sugiyama, T.; Kohara, H.; Noda, M.; Nagasawa, T. Maintenance of the hematopoietic stem cell pool by CXCL12-CXCR4 chemokine signaling in bone marrow stromal cell niches. Immunity 2006, 25, 977-988. [CrossRef] [PubMed]

132. Greenbaum, A.; Hsu, Y.M.; Day, R.B.; Schuettpelz, L.G.; Christopher, M.J.; Borgerding, J.N.; Nagasawa, T.; Link, D.C. CXCL12 in early mesenchymal progenitors is required for haematopoietic stem-cell maintenance. Nature 2013, 495, 227-230. [CrossRef] [PubMed]

133. D’Apuzzo, M.; Rolink, A.; Loetscher, M.; Hoxie, J.A.; Clark-Lewis, I.; Melchers, F.; Baggiolini, M.; Moser, B. The chemokine SDF-1, stromal cell-derived factor 1, attracts early stage B cell precursors via the chemokine receptor CXCR4. Eur. J. Immunol. 1997, 27, 1788-1793. [CrossRef] [PubMed]

134. Karsunky, H.; Inlay, M.A.; Serwold, T.; Bhattacharya, D.; Weissman, I.L. Flk2+ common lymphoid progenitors possess equivalent differentiation potential for the B and T lineages. Blood 2008, 111, 5562-5570. [CrossRef] [PubMed]

135. Holmes, M.L.; Carotta, S.; Corcoran, L.M.; Nutt, S.L. Repression of Flt3 by Pax5 is crucial for B-cell lineage commitment. Genes Dev. 2006, 20, 933-938. [CrossRef] [PubMed]

136. Tsapogas, P.; Swee, L.K.; Nusser, A.; Nuber, N.; Kreuzaler, M.; Capoferri, G.; Rolink, H.; Ceredig, R.; Rolink, A. In vivo evidence for an instructive role of fms-like tyrosine kinase-3 (FLT3) ligand in hematopoietic development. Haematologica 2014, 99, 638-646. [CrossRef] [PubMed]

137. Sitnicka, E.; Bryder, D.; Theilgaard-Monch, K.; Buza-Vidas, N.; Adolfsson, J.; Jacobsen, S.E. Key role of flt3 ligand in regulation of the common lymphoid progenitor but not in maintenance of the hematopoietic stem cell pool. Immunity 2002, 17, 463-472. [CrossRef]

138. Sitnicka, E.; Brakebusch, C.; Martensson, I.L.; Svensson, M.; Agace, W.W.; Sigvardsson, M.; Buza-Vidas, N.; Bryder, D.; Cilio, C.M.; Ahlenius, H.; et al. Complementary signaling through flt3 and interleukin-7 receptor alpha is indispensable for fetal and adult B cell genesis. J. Exp. Med. 2003, 198, 1495-1506. [CrossRef] [PubMed]

139. Schlenner, S.M.; Madan, V.; Busch, K.; Tietz, A.; Laufle, C.; Costa, C.; Blum, C.; Fehling, H.J.; Rodewald, H.R. Fate mapping reveals separate origins of $\mathrm{T}$ cells and myeloid lineages in the thymus. Immunity 2010, 32, 426-436. [CrossRef] [PubMed]

140. Peschon, J.J.; Morrissey, P.J.; Grabstein, K.H.; Ramsdell, F.J.; Maraskovsky, E.; Gliniak, B.C.; Park, L.S.; Ziegler, S.F.; Williams, D.E.; Ware, C.B.; et al. Early lymphocyte expansion is severely impaired in interleukin 7 receptor-deficient mice. J. Exp. Med. 1994, 180, 1955-1960. [CrossRef] [PubMed]

141. Von Freeden-Jeffry, U.; Vieira, P.; Lucian, L.A.; McNeil, T.; Burdach, S.E.; Murray, R. Lymphopenia in interleukin (IL)-7 gene-deleted mice identifies IL-7 as a nonredundant cytokine. J. Exp. Med. 1995, 181, 1519-1526. [CrossRef] [PubMed]

142. Miller, J.P.; Izon, D.; DeMuth, W.; Gerstein, R.; Bhandoola, A.; Allman, D. The earliest step in B lineage differentiation from common lymphoid progenitors is critically dependent upon interleukin 7. J. Exp. Med. 2002, 196, 705-711. [CrossRef] [PubMed]

143. Park, L.S.; Martin, U.; Garka, K.; Gliniak, B.; Di Santo, J.P.; Muller, W.; Largaespada, D.A.; Copeland, N.G.; Jenkins, N.A.; Farr, A.G.; et al. Cloning of the murine thymic stromal lymphopoietin (TSLP) receptor: 
Formation of a functional heteromeric complex requires interleukin 7 receptor. J. Exp. Med. 2000, 192, 659-670. [CrossRef] [PubMed]

144. Chappaz, S.; Flueck, L.; Farr, A.G.; Rolink, A.G.; Finke, D. Increased TSLP availability restores T- and B-cell compartments in adult IL-7 deficient mice. Blood 2007, 110, 3862-3870. [CrossRef] [PubMed]

145. Kondo, M.; Akashi, K.; Domen, J.; Sugamura, K.; Weissman, I.L. Bcl-2 rescues T lymphopoiesis, but not B or NK cell development, in common gamma chain-deficient mice. Immunity 1997, 7, 155-162. [CrossRef]

146. Akashi, K.; Kondo, M.; von Freeden-Jeffry, U.; Murray, R.; Weissman, I.L. Bcl-2 rescues T lymphopoiesis in interleukin-7 receptor-deficient mice. Cell 1997, 89, 1033-1041. [CrossRef]

147. Van der Plas, D.C.; Smiers, F.; Pouwels, K.; Hoefsloot, L.H.; Lowenberg, B.; Touw, I.P. Interleukin-7 signaling in human B cell precursor acute lymphoblastic leukemia cells and murine BAF3 cells involves activation of STAT1 and STAT5 mediated via the interleukin-7 receptor alpha chain. Leukemia 1996, 10, 1317-1325. [PubMed]

148. Dias, S.; Silva, H., Jr.; Cumano, A.; Vieira, P. Interleukin-7 is necessary to maintain the B cell potential in common lymphoid progenitors. J. Exp. Med. 2005, 201, 971-979. [CrossRef] [PubMed]

149. Kosan, C.; Saba, I.; Godmann, M.; Herold, S.; Herkert, B.; Eilers, M.; Moroy, T. Transcription factor miz-1 is required to regulate interleukin-7 receptor signaling at early commitment stages of $\mathrm{B}$ cell differentiation. Immunity 2010, 33, 917-928. [CrossRef] [PubMed]

150. Von Muenchow, L.; Alberti-Servera, L.; Klein, F.; Capoferri, G.; Finke, D.; Ceredig, R.; Rolink, A.; Tsapogas, P. Permissive roles of cytokines interleukin-7 and Flt3 ligand in mouse B-cell lineage commitment. Proc. Natl. Acad. Sci. USA 2016, 113, E8122-E8130. [CrossRef] [PubMed]

151. Malin, S.; McManus, S.; Cobaleda, C.; Novatchkova, M.; Delogu, A.; Bouillet, P.; Strasser, A.; Busslinger, M. Role of STAT5 in controlling cell survival and immunoglobulin gene recombination during pro-B cell development. Nat. Immunol. 2010, 11, 171-179. [CrossRef] [PubMed]

152. Oliver, P.M.; Wang, M.; Zhu, Y.; White, J.; Kappler, J.; Marrack, P. Loss of Bim allows precursor B cell survival but not precursor B cell differentiation in the absence of interleukin 7. J. Exp. Med. 2004, 200, 1179-1187. [CrossRef] [PubMed]

153. Pribyl, J.; LeBien, T.W. Interleukin 7 independent development of human B cells. Proc. Natl. Acad. Sci. USA 1996, 93, 10348-10353.

154. Puel, A.; Ziegler, S.F.; Buckley, R.H.; Leonard, W.J. Defective $I L 7 R$ expression in $\mathrm{T}^{-} \mathrm{B}^{+} \mathrm{NK}^{+}$severe combined immunodeficiency. Nat. Genet. 1998, 20, 394-397. [CrossRef] [PubMed]

155. Shochat, C.; Tal, N.; Bandapalli, O.R.; Palmi, C.; Ganmore, I.; te Kronnie, G.; Cario, G.; Cazzaniga, G.; Kulozik, A.E.; Stanulla, M.; et al. Gain-of-function mutations in interleukin-7 receptor- $\alpha$ (IL7R) in childhood acute lymphoblastic leukemias. J. Exp. Med. 2011, 208, 901-908. [CrossRef] [PubMed]

156. Heltemes-Harris, L.M.; Willette, M.J.; Ramsey, L.B.; Qiu, Y.H.; Neeley, E.S.; Zhang, N.; Thomas, D.A.; Koeuth, T.; Baechler, E.C.; Kornblau, S.M.; et al. Ebf1 or Pax5 haploinsufficiency synergizes with STAT5 activation to initiate acute lymphoblastic leukemia. J. Exp. Med. 2011, 208, 1135-1149. [CrossRef] [PubMed] 